\title{
Predictive Factors of Thyroid Cancer in Geriatric Patients
}

\section{Geriatrik Hastalarda Tiroit Kanserinin Prediktif Faktörleri}

\author{
( ) Serhat Tokgöz, • Harun Karabacak \\ University of Health Sciences Turkey, Dışkapı Yıldırım Beyazıt Training and Research Hospital, Clinic of General Surgery, Ankara, Turkey
}

\begin{abstract}
Aim: Although age is not a contraindication for thyroid surgery, decision for surgery should be made carefully in geriatric patients. The aim of this study was to determine the diagnostic value of cytological and ultrasonographic findings in geriatric patients with thyroid pathology.
\end{abstract}

Methods: Records of patients above 65 years, who underwent thyroid surgery in our clinic between 2014 and 2019, were retrospectively analyzed. Demographic data, biopsy findings according to the Bethesda System, ultrasonography findings (nodule size, echogenicity, margin, micro-calcification, elastography values, peripheral halo and its echogenicity) and pathology results were recorded.

Results: A total of 295 patients (58 males and 237 females) with the mean age of 69.13 years (range; 65-82) were included in the study. When benign and malignant groups were compared, suspicion of malignancy, presence of irregular margins, microcalcification, elastography score of above 3, hypo-echogeneicity and hypo-echoic halo were found to be significant predictive factors for malignancy $(p<0.001)$. When ultrasonography parameters were evaluated with regard to the malignancy risk, specificity was found to be 0.92 for micro-calcification, 0.97 for irregular contour and 0.95 for elastography score above 3 .

Conclusion: The indication for surgery should be supported by ultrasonography and ultrasound elastography findings in patients with atypia/follicular lesion of unknown significance or whose fine needle aspiration biopsy result is non-diagnostic.

Keywords: Thyroid cancer, geriatric, elastography, irregular margins, microcalcification
Öz

Amaç: Yaş, tiroit cerrahisi için bir kontrendikasyon olmamasına rağmen, geriatrik hastalarda operasyon kararı dikkatli bir şekilde verilmelidir. Bu çalışmanın amacı tiroit patolojisi olan geriatrik hastalarda sitolojik ve ultrasonografik bulguların tiroit kanserindeki tanısal değerini belirlemektir.

Yöntemler: 2014-2019 yılları arasında kliniğimizde tiroit cerrahisi geçiren 65 yaş üstü hastaların kayıtları retrospektif olarak incelendi. Demografik veriler, Bethesda Sistemi'ne göre biyopsi sonuçları, ultrasonografi bulguları (nodül boyutu, ekojenite, sınır, mikrokalsifikasyon, elastografi değerleri, periferik halo ve ekojenitesi) ve patoloji sonuçları kaydedildi.

Bulgular: Yaş ortalaması 69,13 (dağılım; 65-82) olan 295 hasta (58 erkek ve 237 kadın) çalışmaya dahil edildi. Benign ve malign gruplar karşılaştııılı̆̆ında biyopside malignite şüphesi, görüntülemede düzensiz sınıların varlığı, mikrokalsifikasyon, üçün üzerinde elastografi skoru, hipoekojenite ve hipoekoik halo malignite için anlamlı bulundu $(p<0,001)$. Ultrasonografi parametreleri malignite riski açısından değerlendirildiğinde, özgüllük mikrokalsifikasyon için 0,92, düzensiz sınır için 0,97 ve üçün üzerindeki elastografi skoru için 0,95 olarak bulunmuştur.

Sonuç: İnce iğne aspirasyon biyopsisi sonucu tanısal olmayan veya önemi bilinmeyen atipi/foliküler lezyon olan hastalarda operasyon endikasyonu ultrasonografi ve ultrason elastografi bulguları ile desteklenmelidir.

Anahtar Sözcükler: Tiroit kanseri, geriatrik, elastografi, düzensiz sınırlar, mikrokalsifikasyon

\section{Introduction}

The prevalence of thyroid nodules increases with age. The rate of nodular thyroid diseases is above $50 \%$ in patients over 65 years of age $(1,2)$. While the vast majority of undifferentiated thyroid cancers are seen in individuals aged 60 years or over, the course of differentiated thyroid cancers is more aggressive in geriatric patients (3).

Life expectancy and quality of life increased with the developments in diagnosis and treatment of chronic
Address for Correspondence/Yazışma Adresi: Serhat Tokgöz, University of Health Sciences Turkey, Dışkapı Yıldırım Beyazıt Training and Research Hospital, Clinic of General Surgery, Ankara, Turkey

Phone: +90 3125962000 E-mail: serhat.tokgoz@yahoo.com ORCID: orcid.org/0000-0003-2716-6222

Received/Geliş Tarihi: 30 March 2020 Accepted/Kabul Tarihi: 26 April 2020

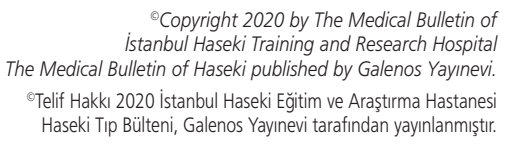

Haseki Tıp Bülteni, Galenos Yayınevi tarafından yayınlanmıştır 
diseases, which are common in the geriatric age group, namely cardiovascular diseases, pulmonary diseases and Diabetes mellitus. Although age is not a contra-indication for thyroid surgery, the decision for operation should be made carefully due to certain morbidities (4).

Indications for thyroidectomy include compressive symptoms such as dysphagia or dyspnea, suspicion of malignancy, substernal goiter, hyperthyroidism resistant to treatment and cosmetic reasons (5). Among these, suspicion of malignancy is the most important and the most challenging indication.

Fine needle aspiration biopsy (FNAB) is the most valuable diagnostic method in decision making for surgery for the treatment of thyroid nodules (6). The Bethesda System for reporting cytopathology is the most commonly used tool for thyroid cytopathology (7). However, this system is not always helpful in decision making for surgery due to the inconsistencies among different centers with regard to the malignancy risk in the categories of nondiagnostic cytology, benign cytology and atypia of undetermined significance/follicular lesion of undetermined significance [atypia of undetermined significance (AUS)/follicular lesion of undetermined significance (FLUS)] (8). Ultrasound findings and clinical features should also be evaluated for surgical decision making in these patients.

The aim of this retrospective study was to determine the diagnostic value of cytological and ultrasonographic findings in patients above 65 years with thyroid pathology.

\section{Methods}

Records of patients above 65 years, who underwent thyroid surgery in our clinic between 2014 and 2019, were retrospectively analyzed. Demographic data, biopsy results according to the Bethesda System, ultrasound findings (nodule size, echogenicity, margin, microcalcification, elastography values, peripheral halo and its echogenicity) and pathology results were recorded. Patients with hyperthyroidism, recurrent thyroid pathology and medullary carcinoma, who had undergone surgery due to definitive regional or distant metastasis and complementary thyroidectomy and thyroidectomy due to parathyroid pathologies, were excluded. A complete physical and laboratory examination was performed pre-operatively in all patients. Vocal cord mobility was evaluated and recorded before surgery. Only patients, who had temporal or permanent vocal cord paralysis, were evaluated with flexible fiberoptic laryngoscopy postoperatively.

In our institution, decision for thyroidectomy is made by a multi-disciplinary endocrinology committee composed of experienced cytopathologists, pathologists, endocrinologists and surgeons. The indications for surgery include nodular goiter, thyrotoxicosis, suspected or verified malignancy, and large and retro-sternal goiter causing tracheal compression. The length of stay in hospital and intensive care unit and the post-operative complications were evaluated in the post-operative period.

Hypocalcemia $(<8 \mathrm{mg} / \mathrm{dL}$ ) persisting for more than 6 months post-operatively was defined as "persistent hypocalcemia".

All procedures performed in studies involving human subjects were in accordance with the ethical standards of the institutional review board (reference no: 54/09) and with the 1964 Helsinki Declaration and its later amendments or comparable ethical standards.

\section{Surgical Technique}

The patient was positioned with hyperextension of the neck following general anesthesia induction. Kocher's incision was made in all cases. The strap muscles were not routinely cut. First, the median vein was ligated and cut, so as to mobilize the gland to the medial. After the upper pole vessels had been isolated, the superior thyroid artery and vein were ligated twice in distal of the bifurcation and above the thyroid capsule. The veins of the inferior pole were ligated individually and cut. The recurrent laryngeal nerve was found at the point where it crossed the thyroid artery and preserved through following along its trace. The parathyroid glands seen in normal location or detected on thyroid capsule were preserved during dissection. No additional dissection was made for the parathyroid glands that could not be visualized. A suction drain was installed in all patients.

\section{Statistical Analysis}

All statistical analyses were performed using the SPSS 22.0 statistical package (SPSS, Chicago, IL, USA). In the descriptive statistics, the data were expressed as mean (standard deviation) for continuous variables, and as frequencies and percentages (\%) for nominal variables. Normality was evaluated with the KolmogorovSmirnov test. The $\chi^{2}$ test was used to assess the presence of significant differences in risk factors between malignant and benign groups. Multiple logistic regression analysis was performed for significant correlations. Receiver operating characteristic (ROC) curves were formed for analysis of the relationship between the risk factors and malignancy. Areas under the curve (AUC), sensitivity and specificity values, Youden index, diagnostic odds ratio (DOR), and positive and the negative likelihood ratio (LR) were determined for each risk factor. Higher AUC, positive $L R$, and $D O R$ indicated a stronger relationship between the risk factor and malignancy (Figure 1). A $p$ value of less than 0.05 was considered statistically significant. 


\section{Results}

A total of 295 patients (58 males and 237 females) with the mean age of 69.13 years (range; 65-82) were included in the study. The patients were divided into two groups as benign and malignant according to the final pathology results. There was no significant difference in mean age between the benign and malignant groups. Of the patients, 285 had pre-operative biopsy results including non-diagnostic $(n=32)$, benign $(n=124)$, AUS $(n=72)$, suspicious for follicular neoplasm $(n=22)$, suspicious for malignancy $(n=27)$ and malignant $(n=8)$. All patients were evaluated with ultrasonography pre-operatively. The mean nodule size was $2.9 \mathrm{~cm}$, microcalcification was found in 100 patients, solid nodule in 23, hypoechogeneity in 48 and hypoechoic nodule in 59 patients. The elastography score was found to be 3 and above in 69 out of 136 patients in whom elastography was performed (Table 1).

When benign and malignant groups were compared, suspicion of malignancy, presence of irregular margins, microcalcification, an elastography score of above 3, hypoechogeneicity and hypoechoic halo were found to

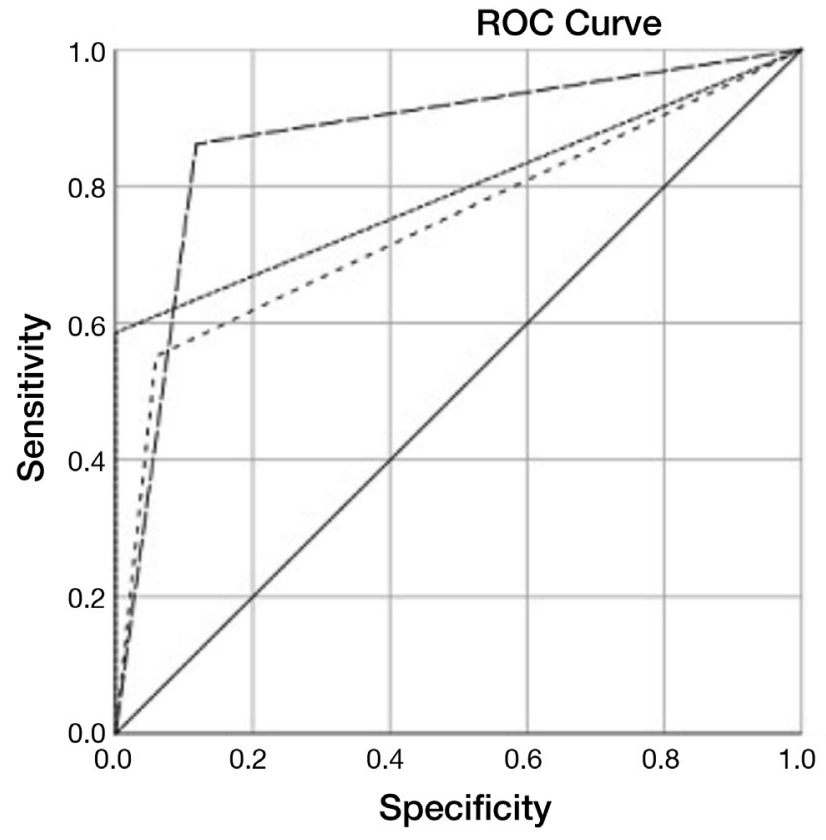

\section{Source of the Curve}

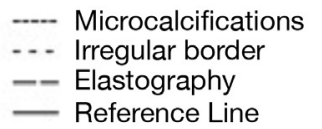

Figure 1. Higher AUC, positive LR, DOR was indicate a stronger relationship between malignancy risk and evaluation method

AUC: Area under the curve, LR: Likelihood ratio, DOR: Diagnostic odds ratio, ROC: Receiver operating characteristic be significant predictive factors for malignancy $(p<0.001)$ (Table 2).

When ultrasonography parameters were evaluated with regard to the malignancy risk, specificity was found to be 0.92 for microcalcification, 0.97 for irregular contour and 0.95 for elastography score above 3 (Table 3 ).

Total thyroidectomy was performed in all patients. The pathology results were reported as benign in 167 patients,

\begin{tabular}{|c|c|}
\hline Variables & Total, [n=295 (100\%)] \\
\hline Age, mean & 69.13 \\
\hline \multicolumn{2}{|l|}{ FNA cytology } \\
\hline Absent & 10 \\
\hline Non diagnostic & 32 \\
\hline Benign & 124 \\
\hline AUS & 72 \\
\hline sFN & 22 \\
\hline sM & 27 \\
\hline Malign & 8 \\
\hline \multicolumn{2}{|c|}{ Microcalcification } \\
\hline Present & 100 \\
\hline Absent & 195 \\
\hline \multicolumn{2}{|c|}{ Irregular margins } \\
\hline Present & 63 \\
\hline Absent & 232 \\
\hline \multicolumn{2}{|l|}{ Solitary nodule } \\
\hline Present & 23 \\
\hline Absent & 272 \\
\hline \multicolumn{2}{|c|}{ Elastography scores } \\
\hline$\geq 3$ & 69 \\
\hline$<3$ & 67 \\
\hline Not evaluated & 159 \\
\hline \multicolumn{2}{|l|}{ Echogenicity } \\
\hline Hypoechoic & 48 \\
\hline Isoechoic & 64 \\
\hline Mix & 171 \\
\hline Hiper & 12 \\
\hline \multicolumn{2}{|l|}{ Gender } \\
\hline Male & 58 \\
\hline Female & 237 \\
\hline \multicolumn{2}{|l|}{ Nodule size } \\
\hline$\geq 2 \mathrm{~cm}$ & 201 \\
\hline$<2 \mathrm{~cm}$ & 94 \\
\hline \multicolumn{2}{|c|}{ Hypoechoic halo } \\
\hline Present & 59 \\
\hline Absent & 236 \\
\hline \multicolumn{2}{|c|}{$\begin{array}{l}\text { FNA: Fine needle aspiration, AUS: Atypia of undetermined significance } \\
\text { sFN: Suspicious for follicular neoplasm, sM: Suspicious for malignancy, US } \\
\text { Ultrasonography, n: Number }\end{array}$} \\
\hline
\end{tabular}




\begin{tabular}{|c|c|c|c|c|}
\hline Variables & $\begin{array}{l}\text { Total, } \\
{[\mathrm{n}=295(100 \%)]}\end{array}$ & $\begin{array}{l}\text { Benign group, } \\
{[n=167(56.6 \%)]}\end{array}$ & $\begin{array}{l}\text { Malignant group, } \\
{[n=128(43.4 \%)]}\end{array}$ & $p$ value \\
\hline Age, mean & 69.13 & 69.08 & 69.20 & 0.731 \\
\hline \multicolumn{5}{|l|}{ FNA cytology } \\
\hline Absent & 10 & 4 & 6 & 0.282 \\
\hline Non diagnostic & 32 & 22 & 10 & 0.143 \\
\hline Benign & 124 & 99 & 25 & 0.001 \\
\hline AUS & 72 & 33 & 39 & 0.034 \\
\hline sFN & 22 & 7 & 15 & 0.015 \\
\hline sM & 27 & 2 & 25 & $<0.001$ \\
\hline Malign & 8 & 0 & 8 & 0.001 \\
\hline \multicolumn{5}{|c|}{ Microcalcification } \\
\hline Present & 100 & 12 & 88 & \multirow{2}{*}{$<0.001$} \\
\hline Absent & 195 & 155 & 40 & \\
\hline \multicolumn{5}{|l|}{ Irregular margins } \\
\hline Present & 63 & 4 & 59 & \multirow{2}{*}{$<0.001$} \\
\hline Absent & 232 & 163 & 69 & \\
\hline \multicolumn{5}{|l|}{ Solitary nodule } \\
\hline Present & 23 & 10 & 13 & \multirow{2}{*}{0.121} \\
\hline Absent & 272 & 157 & 115 & \\
\hline \multicolumn{5}{|c|}{ Elastography scores } \\
\hline$\geq 3$ & 69 & 3 & 66 & \multirow{2}{*}{$<0.001$} \\
\hline$<3$ & 67 & 57 & 10 & \\
\hline \multicolumn{5}{|l|}{ Echogenicity } \\
\hline Hypoechoic & 48 & 7 & 41 & \multirow{4}{*}{$<0.001$} \\
\hline Isoechoic & 64 & 43 & 21 & \\
\hline Mix & 171 & 108 & 63 & \\
\hline Hiper & 12 & 9 & 3 & \\
\hline \multicolumn{5}{|l|}{ Gender } \\
\hline Male & 58 & 34 & 24 & \multirow{2}{*}{0.731} \\
\hline Female & 237 & 133 & 104 & \\
\hline \multicolumn{5}{|l|}{ Nodule size } \\
\hline$\geq 2 \mathrm{~cm}$ & 201 & 118 & 83 & \multirow{2}{*}{0.343} \\
\hline$<2 \mathrm{~cm}$ & 94 & 49 & 45 & \\
\hline \multicolumn{5}{|c|}{ Hypoechoic halo } \\
\hline Present & 59 & 14 & 45 & \multirow{2}{*}{$<0.001$} \\
\hline Absent & 236 & 153 & 83 & \\
\hline
\end{tabular}

\begin{tabular}{|c|c|c|c|c|c|c|c|}
\hline & AUC & Sen. & Spc. & LR+ & LR- & DOR & YI \\
\hline Presence of microcalcification & 0.793 & 0.68 & 0.92 & 9.57 & 0.34 & 9.23 & 0.60 \\
\hline Presence of irregularity & 0.746 & 0.45 & 0.97 & 19 & 0.56 & 33.92 & 0.42 \\
\hline Elastography scores $\geq 3$ & 0.872 & 0.86 & 0.95 & 17 & 0.14 & 121.42 & 0.81 \\
\hline
\end{tabular}


papillary micro-carcinoma in 62, papillary carcinoma in 55 and follicular carcinoma in 11 patients.

The post-operative complications included temporally dysphonia (1-2\%), permanent hypocalcemia (1-2\%) and transient hypocalcemia (30\%). While re-exploration was necessary in two patients due to post-operative hemorrhage, the rate of wound site infection was $1.5 \%$. No permanent dysphonia and death occurred.

While the mean length of hospital stay was found to be 3.1 days (range; 2-7), the mean intensive care unit length of stay was 1.4 days (range; 1-3) in 18 patients who required intensive care.

\section{Discussion}

Recent studies have indicated that thyroid surgery could be performed with low mortality and morbidity rates even in the elderly $(9,10)$. However, it is essential to make an individual risk and benefit analysis in elective thyroid surgery, particularly in geriatric patients $(10,11)$. The vast majority of thyroidectomy indications are composed of high suspicion of malignancy, resistant thyrotoxicosis and large thyroid leading to compression symptoms in geriatric patients. While it is easy to make a diagnosis of thyrotoxicosis and compression symptoms, it is necessary to use clinical, cytological and ultrasonographic properties in cases suspicious for malignancy and their predictive values should be great.

FNAB is accepted as the most reliable diagnostic tool for discrimination of benign and malignant thyroid nodules. It has a high specificity (72-100\%) and sensitivity (65-98\%). While the false positive rate of this method is $0-7 \%$ for detection of malignant tumors, the false negative rate is $1-11 \%$. The diagnostic value of the method increases when performed under ultrasound guidance. FNAB is the first choice in the diagnosis of thyroid nodules due to having low complication rates, being well tolerated by the patients and cost-effective, not requiring hospitalization and yielding accurate results $(6,12)$.

The Bethesda System is a reporting system created for cytopathology reports of fine needle aspiration biopsies of the thyroid gland. The system aims at standardizing the diagnoses by making a categorization and improving communication between pathologists and clinicians. This reporting system was first introduced in 2009 and revised in 2017. The diagnosis groups, which are still being used, were preserved after the revision. While the malignancy risk of AUS was $5-15 \%$ according to the Bethesda System, the rate of malignancy was found to be $54.1 \%$ in our study. While the malignancy risk is $15-30$ in patients undergoing surgery due to the diagnosis of follicular lesion, this rate was $68.1 \%$ in our study. In a meta-analysis of eight studies performed by Bongiovanni in 2012, the rate of malignancy was reported to be $15.9 \%$ and $26.1 \%$ for AUS and FLUS, respectively (13-15). However, there are also studies reporting opposite results. In their study analyzing the results of 3207 FNABs, Theoharis et al. (16) reported that the risk of malignancy was $48 \%$ and $34 \%$ for AUS and FLUS, respectively. The striking high rates of AUS and FLUS were associated with the fact that only some part (30\%) of these patients had undergone surgery. The malignancy rates were reported as $18.9 \%$ and $45.7 \%$, respectively, in a study by Onder et al. (17), which investigated the effectiveness of the Bethesda System for detecting malignancy risk in undetermined cases. The high rates in our study could be associated with the fact that we considered ultrasonography findings and elastography findings besides the diagnosis of AUS when deciding the indications for operation.

In the literature, benign thyroid nodules have been reported to be sharp and well demarcated, and malignant nodules have been reported to be irregular and poorly demarcated. Although the histological characteristics consistent with the contour structure of the nodule could not be clearly explained, irregular and speculated contour structure has been reported to be specific for malignant nodules (18). In our study, while the absence of an irregular margin was significant in benign nodules, it was not found to be statistically significant in malignant nodules.

It has been reported that calcification could be detected in 10-15\% of all thyroid nodules; however, the pattern and the location of the calcification rather than its presence was important for discrimination of malignancy. Intrinsic microcalcifications have been reported to increase the suspicion of malignancy in thyroid nodules (19). In our study, while the rate of malignancy was $88 \%$ in the presence of microcalcification on ultrasonography, this rate was $20.5 \%$ in the absence of microcalcification. Ultrasound elastography is an imaging method developed for noninvasively assessing the tissue firmness. The method evaluates the distortion developing with an external compression (20). Elastography is an imaging method used for evaluating the mechanic and elastic properties of soft tissue and is mainly based on the structural organization and composition of macromolecules. Pathological processes change the tissue structure and consequently its elastic properties. Malignant thyroid nodules are usually firmer than benign nodules. This characteristic is more evident in papillary carcinoma. In our study, while the elastography score was $>3$ in 69 patients, the rate of malignancy was $95 \%$ and the rate of benign nodules was $85 \%$ in those with an elastography score of $<3$. Although the rates found in our study were consistent with the literature, the mean values vary between $45 \%$ and $89 \%$ in the literature (21-23). 
In the literature, ultrasound and cytopathological features of malignant nodules in geriatric patients mostly seem the same as in young patients (24). In our study, the rate of malignancy was higher in the postoperative pathology, since ultrasound elastography was used and the operation decision was made more selectively.

The results of the study helped us make a diagnosis for operation strongly in patients whose FNAB result was non-diagnostic or AUS.

In studies evaluating complications, no significant difference could be found between young and elderly patients who had undergone a thyroid surgery. Passler et al. (9) compared the results of 55 patients aged 75 years and over (mean; 80) with 683 younger ones and found that the rate of early complications in patients older and younger than 75 years was $25.5 \%$ and 21.8 , respectively. While the rates of hematoma, seroma, transient or permanent recurrent nerve palsy, transient and permanent hypocalcemia were found to be similar between young and elderly patients in the literature, the incidence of temporal dysphonia, permanent dysphonia, transient hypocalcemia and permanent hypocalcemia was found to be $1-2 \%, 0 \%, 30 \%$ and $1-2 \%$, respectively, in our study. While 2 patients were re-explored due to post-operative hemorrhage, the rate of wound site infection was $1.5 \%$. Despite the risk of morbidity is high in the elderly, the rate in our study is consistent with the literature (9). There was no mortality in our study and this was consistent with the literature (25).

\section{Study Limitations}

Our study has several limitations. The study was retrospective, small sample size of patients and lack of data from the young group, and also in our study, making the operation decision more clearly in the geriatric group had a positive effect on our study.

\section{Conclusion}

Thyroidectomy has better morbidity and mortality rates compared to other elective operative procedures in the elderly due to being quite a safe surgical procedure. Age is not a contra-indication alone for surgeons experienced in thyroid surgery and it should be evaluated together with comorbid diseases. The indication for surgery should be supported by ultrasonography and ultrasound elastography findings in patients whose FNAB result is AUS. A well preoperative preparation would decrease the risk of complications and mortality. Further studies evaluating the influence of age on complications in elderly patients are needed.

\section{Authorship Contributions}

Concept: S.T. Design: S.T. Data Collection or Processing: S.T., H.K. Analysis or Interpretation: S.T. Literature Search: S.T., H.K. Writing: S.T., H.K.

Conflict of Interest: The authors have no conflict of interest to declare.

Financial Disclosure: The authors declared that this study has received no financial support.

\section{References}

1. Mekel M, Stephen AE, Gaz RD, Perry ZH, Hodin RA, Parangi $\mathrm{S}$. Thyroid surgery in octogenarians is associated with higher complication rates. Surgery 2009;146:913-21.

2. Seybt MW, Khichi S, Terris DJ. Geriatric thyroidectomy safety of thyroid surgery in an aging population. Arch Otolaryngol Head Neck Surg 2009;135:1041-4.

3. Kauffmann RM, Hamner JB, Ituarte PHG, Yim JH. Age greater than 60 years portends a worse prognosis in patients with papillary thyroid cancer: should there be three age categories for staging? BMC Cancer 2018;18:316.

4. Ríos A, Rodríguez JM, Galindo PJ, Canteras M, Parrilla P. Surgical treatment for multinodular goitres in geriatric patients Langenbecks Arch Surg 2005;390:236-42.

5. American Thyroid Association (ATA) Guidelines Taskforce on Thyroid Nodules and Differentiated Thyroid Cancer, Cooper DS, Doherty GM, et al. Revised American Thyroid Association management guidelines for patients with thyroid nodules and differentiated thyroid cancer. Thyroid 2009;19:1167-214.

6. Hong MJ, Na DG, Lee H. Diagnostic efficacy and safety of core needle biopsy as a first-line diagnostic method for thyroid nodules: a prospective cohort study. Thyroid 2019;30:1141-9.

7. Theoharis CGA, Schofield KM, Hammers L, Udelsman R, Chhieng DC. The Bethesda thyroid fine-needle aspiration classification system: year 1 at an academic institution. Thyroid 2009;19:1215-23.

8. Yoon JH, Kwon HJ, Kim EK, Moon HJ, Kwak JY. Subcategorization of atypia of undetermined significance/ follicular lesion of undetermined significance (AUS/FLUS): a study applying Thyroid Imaging Reporting and Data System (TIRADS). Clin Endocrinol (Oxf) 2015;85:275-82.

9. Passler C, Avanessian R, Kaczirek K, Prager G, Scheuba C, Niederle B. Thyroid surgery in the geriatric patient. Arch Surg 2002;137:1243-8.

10. Raffaelli $M$, Bellantone $R$, Princi $P$, et al. Surgical treatment of thyroid diseases in elderly patients. Am J Surg 2010;200:46772.

11. Yu L, Hong $H$, Han J, Leng SX, Zhang $H$, Yan X. Comparison of Survival and Risk Factors of Differentiated Thyroid Cancer in the Geriatric Population. Front Oncol 2020;10:42.

12. Tamhane S, Gharib H. Thyroid nodule update on diagnosis and management. Clin Diabetes Endocrinol 2016;2:17. 
13. Kaliszewski K, Diakowska D, Wojtczak B, et al. Fine-Needle Aspiration Biopsy as a Preoperative Procedure in Patients with Malignancy in Solitary and Multiple Thyroid Nodules. PLoS One 2016;11:e0146883.

14. Nikiforov YE, Ohori NP, Hodak SP, et al. Impact of mutational testing on the diagnosis and management of patients with cytologically indeterminate thyroid nodules: a prospective analysis of 1056 FNA samples. J Clin Endocrinol Metab 2011;96:3390-7.

15. Bongiovanni M, Spitale A, Faquin WC, Mazzucchelli L, Baloch ZW. The Bethesda System for Reporting Thyroid Cytopathology: a meta-analysis. Acta Cytol 2012;56:333-9.

16. Theoharis CGA, Schofield KM, Hammers L, Udelsman R, Chhieng DC. The Bethesda thyroid fine-needle aspiration classification system: year 1 at an academic institution. Thyroid 2009;19:1215-23.

17. Onder S, Firat P, Ates D.The Bethesda system for reporting thyroid cytopathology: an institutional experience of the outcome of indeterminate categories. Cytopathology 2014;25:177-84

18. Moon WJ, Jung SL, Lee JH, et al. Benign and malignant thyroid nodules: US differentiation-multicenter retrospective study. Radiology 2008;247:762-70.

19. Melany M, Chen S. Thyroid Cancer Ultrasound Imaging and Fine-Needle Aspiration Biopsy. Endocrinol Metab Clin North Am 2017;46:691-711.
20. Monpeyssen H, Tramalloni J, Poirée S, Hélénon O, Correas JM. Elastography of the thyroid. Diagn Interv Imaging 2013;94:535-44.

21. Wang Y, Dan HJ, Dan HY, Li T, Hu B. Differential diagnosis of small single solid thyroid nodules using real-time ultrasound elastography. J Int Med Res 2010;38:466-72.

22. Xing $P$, Wu L, Zhang C, Li S, Liu C, Wu C. Differentiation of benign from malignant thyroid lesions: calculation of the strain ratio on thyroid sonoelastography. J Ultrasound Med 2011;30:663-9.

23. Ning $C P$, Jiang SQ, Zhang T, Sun LT, Liu YJ, Tian JW. The value of strain ratio in differential diagnosis of thyroid solid nodules. Eur J Radiol 2012;81:286-91.

24. Dellal FD, Özdemir D, Tam AA, et al. Clinicopathological features of thyroid cancer in the elderly compared to younger counterparts: single-center experience. J Endocrinol Invest 2017;40:471-9.

25. Serkan T, Akif Enes A, Şafak Emre E, et al, Effect of total thyroidectomy on mortality and morbidity in geriatrıc patients: Cerrahpasa experience. Turkish Journal of Geriatrics 2013;16:365-71. 